\title{
A Review on the Adverse Impacts of Cadmium on Ecosystem and its Refinement Strategies
}

\author{
Khaliq Dad ${ }^{1}$, Muhammad Nawaz ${ }^{2 *}$, Muhamamd Ibrahim ${ }^{3}$, Fengliang Zhao ${ }^{4}$, Rumsha Hassan ${ }^{2}$, Humaira \\ $\mathrm{Nawaz}^{5}$, Muhammad Usman Saleem ${ }^{6}$, Kinat Javed ${ }^{2}$, Ayesha Komal ${ }^{2}$ and Hajra $\mathrm{Naz}^{2}$
}

\begin{abstract}
${ }^{1}$ Government Degree Boys College, Shah Sadder Din, D. G.Khan, Pakistan; ${ }^{2}$ Department of Environmental Sciences, Bahauddin Zakariya University, Multan, Pakistan; ${ }^{3}$ Department of Biochemistry, Bahauddin Zakariya University, Multan, Pakistan; ${ }^{4}$ Institute of Environmental and Plant Protection, Chinese Academy of Tropical Agriculture Science, Haikou, Hainan, China; ${ }^{5}$ College of Earth and Environmental Science, University, of Punjab, Lahore, Pakistan; ${ }^{6}$ Department of Biosciences, Bahauddin Zakariya University, Multan, Pakistan.
\end{abstract}

\begin{abstract}
Cadmium (Cd) is highly toxic metal which naturally exists in environment in small proportion but continuously increasing due to anthropogenic activities. The rapid increase in population is putting pressure on urbanization, agriculture and industrialization which have resulted in gradual increase in $\mathrm{Cd}$ level. It is released from industries as an impurity and pollutes soil, water and air in different ways. High solubility in water increases its mobility in the soil ecosystem. The use of sludge and chemical sprays on crops increase the $\mathrm{Cd}$ contamination besides some other heavy metals. Through nutrient cycling, it is taken up from the soil to plants and finally becomes the part of human body which warrants serious health concerns. Cadmium causes mild to severe effects on plants, animals and environmental health. Humans are exposed to cadmium through food, water intake, inhalation (cigarette) and dermal contact which then produces heart disease, kidney failure, lung cancer, orthopedic disease, nervous system failure, low immunity level, mental retardation and growth retardation. Different environmental friendly and low cost biological remedies are used nowadays to control $\mathrm{Cd}$ toxicity such as phytoremediation phytostabilisation, rhizofilteration, phytoextraction. This review paper has summarized the impact of $\mathrm{Cd}$ on soil, plants and humans and strategies to remove or minimize its toxicity by applying some low cost and environmental friendly techniques.

Received | June 27, 2021; Accepted | September 07, 2021; Published | October 14, 2021

*Correspondence | Muhammad Nawaz, Department of Environmental Sciences, Bahauddin Zakariya University, Multan, Pakistan; Email: mnawaz@bzu.edu.pk

Citation | Dad, K., M. Nawaz, M. Ibrahim, F. Zhao, R. Hassan, H. Nawaz, M.U. Saleem, K. Javed, A. Komal and H. Naz. 2021. A review on the adverse impacts of cadmium on ecosystem and its refinement strategies. Pakistan Journal of Agricultural Research, 34(4): 799-812.

DOI | https://dx.doi.org/10.17582/journal.pjar/2021/34.4.799.812

Keywords | Cadmium toxicity, Sources, Environmental impacts, Remediation techniques
\end{abstract}

\section{Introduction}

$\mathrm{C}$ admium is highly toxic element abundantly found in nature, and an important component of earth layer (crust) including soil, water, air, underground soil, mines, plant tissues, animal tissues, and ores. Cadmium may cause adverse effects on human, animal and plants health especially when its concentration exceeds the limit due to continuous produc- tion. Cadmium ranges in earth crust between 0.1 to $0.5 \mathrm{ppm}$, in marine Because of high environmental and human health concerns, a lot of research has been done over the past 50 years. Sources of $\mathrm{Cd}$ emission are both natural and anthropogenic (manmade). Total $\mathrm{Cd}$ emission from natural sources ranges from 10-50\% (Morrow et al., 1995; Nawrot et al., 2006). Mining activities are the biggest source of $\mathrm{Cd}$ emission in environment and contaminate soil, air, water December 2021 | Volume 34 | Issue 4 | Page 799 
and land in many ways. Volcanic eruption, soil erosion and forest fires also contribute in gradual rise of cadmium in environment (Sarkar et al., 2013; Tinkov et al., 2017). Due to agricultural, industrial and urban sector revolution, there is an increase in the use and the production of $\mathrm{Cd}$ all over the world directly and indirectly. So, there is a dire need to check the sources of cadmium discharge and their primary and secondary effects on humans, animals, soil and vegetation (Page et al., 1973).

Because of water scarcity issue all over the world, there is a lack of fresh water to irrigate the agricultural land, so in many countries including Pakistan, industrial and urban sewage runoff is used for irrigation purposes. This effluent contains heavy metals that are toxic in nature. These toxic metals are non-biodegradable and can remain in soil for so long. Toxic heavy metals include Cadmium (Cd), Lead $(\mathrm{Pb})$, Nickel $(\mathrm{Ni})$, and Chromium $(\mathrm{Cr})$. These metals assimilate with soil and start to accumulate in roots, shoot and leafy parts of the plant (Perveen et al., 2012; Rehman et al., 2015). Municipal sewage water may also suppress organic matter, micronutrients and minerals such as phosphorus, calcium, zinc, etc. Organic matter and minerals nourishes the soil but irrigate the soil with this highly contaminated water for so long and exceed the toxicity level in soil that may affect the soil fertility, reduce the plant growth and crop production (Nawaz et al., 2016). Most particularly cadmium toxicity is linked with our body through food chain in the form of many chronic and acute diseases i.e. renal and hepatic dysfunction, pulmonary edema, testicular damage, damage to the adrenal glands and haematopoietic system (Tinkov et al., 2017).

When $\mathrm{Cd}$ accumulates in different parts of the plant like root, shoot, and leaves, it causes many adverse effects on plants. The most common effects include impedance of root and shoot growth, decreased nutrient uptake capacity of plants, damage to chloroplast, reduced chloroplast content, drop out of photosynthesis activity, change in stomata activity, decreased transpiration rate, decreased water contents and necrosis due to enzyme metabolism. Change in nitrogen cycle that stops plant growth has also been observed (Genchi et al., 2020). By the use of Transfer Factor (TF), Daily Metal Intake (DIM), Health Risk Index (HRI) and Health Quotient (HQ) we can find out the health risks associated with $\mathrm{Cd}$ toxicity (Sardar et al., 2013).
Physicochemical properties and sources of Cadmium As shown in the (Table 1, Figure 1) Cd is highly abundant and lethal in nature. This is symbolically represented by $\mathrm{Cd}$ with atomic number 48 and oxidation state is ${ }^{+2}$. It exists in nature as cadmium hydroxide $\mathrm{Cd}(\mathrm{OH})_{2}$ cadmium carbonate $\mathrm{CdCO}_{3}$ and cadmium sulphate $\mathrm{CdSO}_{4}$. $\mathrm{Cd}$ is soft in nature, insoluble in water, not flammable, good conductor of electricity, low melting point. On burning cadmium oxide is formed. It is highly reactive in nature. It forms cadmium chloride, cadmium sulphate, and cadmium nitrate when react with hydrochloric acid, sulphuric acid and nitric acid, respectively (Blanusa at el., 2005; Mahajan and Kaushal, 2018).

\section{Table 1: Physical and chemical properties of cadmium} (Genchi et al., 2020).

$\begin{array}{lll}1 & \text { Atomic number } & 48 \\ 2 & \text { Atomic radius } & 155 \mathrm{pm} \\ 3 & \text { Melting point } & 321.07 \mathrm{C} \\ 4 & \text { Density at 20_C } & 8.65 \mathrm{~g} / \mathrm{cm}^{3} \\ 5 & \text { Reduction potential Cd } \mathrm{Cd}^{2+}+2 \mathrm{e} \rightarrow ! \mathrm{Cd}(\mathrm{s}) & -0.40 \mathrm{E}^{\circ} \\ 6 & \text { Heat of vaporization } & 99.6 \mathrm{~kJ} / \mathrm{mol} \\ 7 & \text { First ionization energy } & 867.8 \mathrm{~kJ} / \mathrm{mol} \\ 8 & \text { Atomic weight } & 112.41 \mathrm{u} \\ 9 & \text { Electronic configuration } & {[\mathrm{Kr}] 4 \mathrm{~d}^{10} 5 \mathrm{~s}^{2}} \\ 10 & \text { Boiling point } & 767.3 \mathrm{C} \\ 11 & \text { Heat of fusion } & 6.21 \mathrm{~kJ} / \mathrm{mol} \\ 12 & \text { Electronegativity (Pauling scale) } & 1.69 \\ 13 & \text { Second ionization energy } & 1631.4 \mathrm{~kJ} / \mathrm{mol}\end{array}$

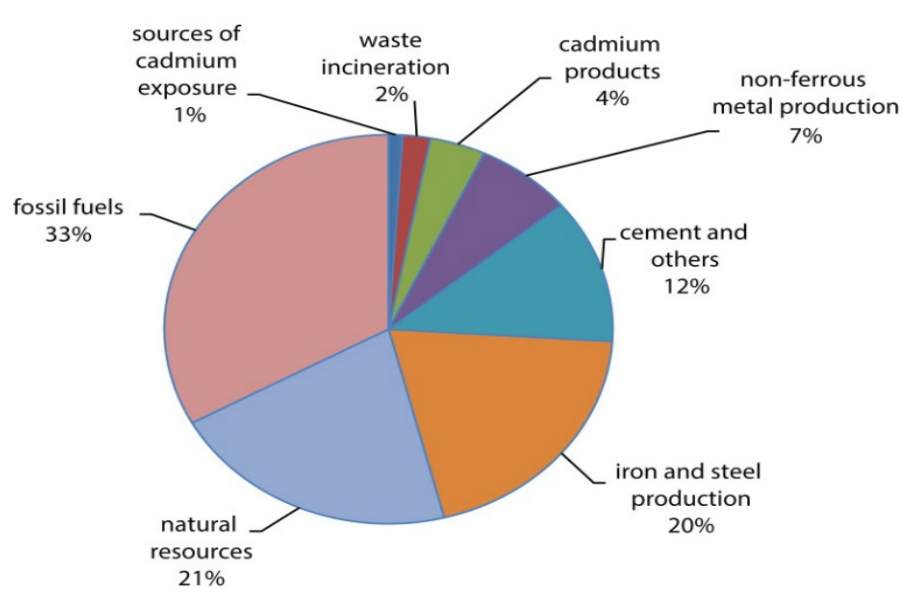

Figure 1: Relative contribution of different sources to cadmium exposure (Jaishankar et al., 2014).

In nature, $\mathrm{Cd}$ is highly toxic metal and carcinogenic in nature. This metal exists everywhere in environment. Above the threshold limit, $\mathrm{Cd}$ gives rise to environmental pollution in the form of human health 
risk. Cadmium toxicity occurs in human body when exposed to contaminated air, water and food. Cadmium has no taste, no odor that's why we cannot feel its presence in environment. Some serious diseases caused by $\mathrm{Cd}$ poisoning include itai-itai disease and arsenicosis. Cadmium remains in human body for many years. Its half-life in human body is approximately 30 years. When a baby is born, no cadmium found in its body but with age and environmental exposure $\mathrm{Cd}$ start to accumulate in body and at the age of 40 "s its concentration is 20 to $30 \mathrm{ug}$ that is not a safe level for a human being. Sometime it may extend to very high levels as $200-300 \mathrm{mg}$ in people who are subjected to workplaces on daily basis which is highly toxic. In human body there is no well-defined metabolism for its removal/excretion therefore, it remains in body till death (Bernard and Lauwerys, 2006). Both primary and secondary sources contribute in polluting the environment either directly or indirectly, and cause intense effects on humans, plants and animals at a slight exposure (Mahajan and Kaushal, 2018). Cd affect the mineral availability, reduces soil microorganisms' population, stomata opening, and transpiration rate, inhibit nitrogen cycle, and reduce nitrogen fixation (Benavides et al., 2005; Zwolak, 2020).

\section{Other sources}

Naturally nutrients are present in soil but to boost up the food production and quality, additional nutrients are required i.e., not only macronutrients $(\mathrm{N}, \mathrm{P}, \mathrm{K}, \mathrm{S}$, $\mathrm{Ca}$, and $\mathrm{Mg}$ ), but also essential micronutrients. Heavy metals also required for plant growth within a specific limit. Metal content is lower in some sites that can be increased by the continuous use of fertilizer (Scragg, 2005). In several Asian and African countries, studies have suggested that agriculture based on wastewater irrigation accounted for 50 percent of the vegetable supply to urban areas (Sumner, 2000).

Livestock, compost and municipal sewer muck are considered as bio-solids. Bio-solids are organic in nature and considered as much effective and advantageous than sludge. The main reason to give the priority to bio-solids over sludge is composting bio-solids with other organic materials such as sawdust, straw, or garden waste (Lasat, 1999). Animal manure is applied on agricultural sites in two different forms, either in solid form or as slurries. As $\mathrm{Cu}$ and $\mathrm{Zn}$ level is usually high in the manure, its continuous use can contaminate the soil (Mattigod et al., 1983). It is not necessary to always apply sludge in soil because sludge compo- sition varies in nature that is based on their emission source (Scott and Smith 1995; Fytili and Zabaniotou 2008). Underground fresh water sources are continuously depleted because of excessive use and wastage of water at commercial, industrial and household level. This can also be a source of heavy metals. To fulfill the water requirements for commercial and agricultural level municipal and industrial waste water is recycled through different processes, but at limited scale. According to a survey report 20 million hectares of agricultural land is irrigated with waste water; $60 \%$ of food supply is based on agricultural land which contain heavy metals (Chaney et al., 1996).

\section{Uptake, transportation and toxicity mechanism of $C d$ in plants}

Many studies have been done on understanding the uptake and receptivity procedure of $\mathrm{Cd}$ in different parts of plants (Lin et al., 2007). Entry route of Cd in roots and leaves depends on the assemblage and allocation factors (Song et al., 2016) (Table 5). A lot of researches have been done on $\mathrm{Cd}$ conglomeration and reclamation in plants. To detoxify the $\mathrm{Cd}$ toxicity from soil special plant species are required. These plants have special cells and vacuole that help in reclamation process. Cadmium enters into the plants in three ways i.e., adsorption, transportation and translocation. Roots are the main source of $\mathrm{Cd}$ adsorption. Cadmium adsorption depends on $\mathrm{pH}$, humic acid content and characteristics of adsorbing material. Root hairs at the apex exhibit better capacity for $\mathrm{Cd}$ adsorption by increasing the surface area. Cadmium adsorption takes place in the form of cation ions which holds positive charge $\mathrm{Cd}^{2+}$. In plants for adsorption, root hairs are considered as the main part.

Transportation mechanism is done by two paths, apoplast and symplast (Lin et al., 2012). Cadmium entry into the plant through root cells mainly takes place through the exchange of ions, the release of organic acids, chelating to metal ions and sequestration to root cells. Type of metals, its mechanism of entry, and plant characteristics provide base for transportation (Sing and Agrawal, 2007; Lin and Aarts, 2012). Factors like soil $\mathrm{Cd}$ content, soil $\mathrm{pH}$, organic matter, clay minerals, cation exchange capacity (CEC) and type of fertilizers control $\mathrm{Cd}$ presence in soil. Cadmium uptake depends upon soil pH (Pers et al., 2013; Cieslinski et al., 1998). In wheat cultivated soil, air pollution, soil classification and wheat farming influence the cadmium intake. The presence of chloride ion 
in soil can intensify the uptake mobility of $\mathrm{Cd}$ by a wheat plant. The uptake mobility of $\mathrm{Cd}$ by a plant can intensify in the presence of chloride ion in soil. Cadmium distribution is always from root to shoot (as diffusion), from higher to lower concentrated parts of plants (Dahlin et al., 2016).

There is a possibility that $\mathrm{Cd}$ holding capacity of roots elevate as a result of bonding between ions and metallic ions (Szolnoki et al., 2013; Rizwan et al., 2016). Hydroxyl radical, peroxide, superoxide, alpha oxide, reactive oxygen species and presence of highly reactive species are also the reason of $\mathrm{Cd}$ uptake in the pants. Cadmium exposure to plants may reduce the plant growth and increase plant stress as a result of malondialdehyde (MDA) production (Table 2). Cadmium toxicity causes membrane injury which is vital part for mineral absorption from soil, as a result of membrane injury it can affect the mineral exchange between soil and plant (Abbas et al., 2017). Cadmium toxicity at higher level affects plants in the form of leaf damage, reduced food production and chloroplast damage (Teng et al., 2007).

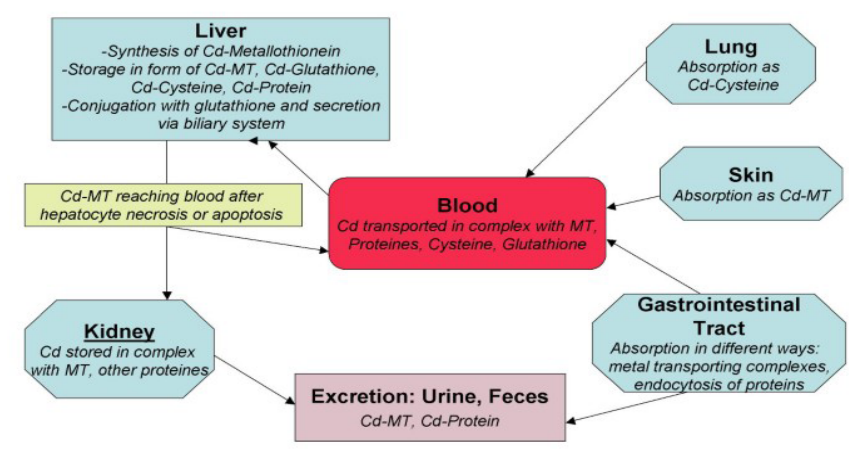

Figure 2: The toxicity of cadmium and resulting hazards for human bealth (Godt et al., 2006)

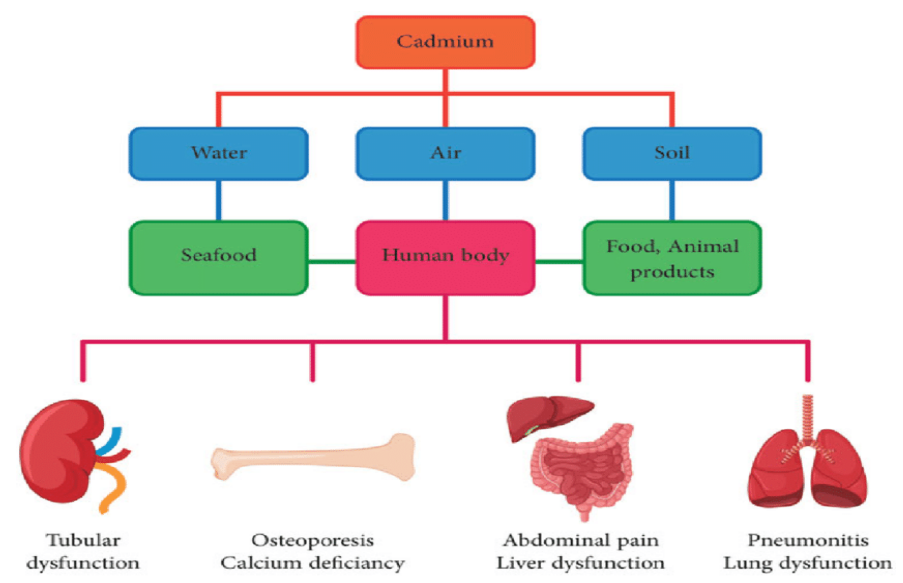

Figure 3: The effects of cadmium exposure in the induction of inflammation (Hossein et al., 2020).
Cadmium uptake and distribution in human Body Human body is exposed to $\mathrm{Cd}$ toxicity directly as well as indirectly; directly through dermal contact and inhalation while indirectly through vegetables and crop consumption (Figure 2 and 3, Table 3 and 4). The $\mathrm{Cd}$ moves from soil to plant roots and then become the part of edible parts of the plants. The $\mathrm{Cd}$ then becomes the part of human body (Alloway and Steinnes, 1999). About $90 \%$ of human exposure to $\mathrm{Cd}$ is from cereals and vegetables specially lettuce, cabbage, beets, coriander, radishes, carrots, spinach, parsley and potato. Cadmium intake mechanism in body depends on age, sex, nutrient level, diet composition, exposure duration and exposure dose (Gustin et al., 2018; Akesson et al., 2008). It is observed that people with low hemoglobin level are more vulnerable to $\mathrm{Cd}$ exposure and accumulation ratio is $6 \%$ higher than the normal ones. So, people with anemia (low hemoglobin level) mostly children and women during menstruation are at risk. Low iron levels provoke the ion carrier protein, which carry $\mathrm{Cd}$ into gastrointestinal track. (Godt et al., 2006). Cadmium intake through food is not only limited to plants and cereal consumption, also includes sea food like fish and prawns. Among the sea food, fish is the greatest source of $\mathrm{Cd}$ intake because of two reasons: (1) fish contains high Cd level and (2) fish is the greatest food source of people living at coastal areas (Fatima et al., 2019). Cigarette smoke is another source of $\mathrm{Cd}$ exposure to lungs as the smoke of cigarette contains two times more $\mathrm{Cd}$. The most important metabolic parameter for $\mathrm{Cd}$ uptake is a person's possible lack of iron. People with low iron supplies have shown $6 \%$ higher uptake of $\mathrm{Cd}$ than those with a balanced iron stock. This is the main reason for the higher $\mathrm{Cd}$ re-absorption in people with anemia and habitual iron deficit, such as children or menstruating women. Low iron blood levels stimulate the expression of DCT-1, a metal ion transporter in the $\mathrm{GI}$ tract, serving as a gate for $\mathrm{Cd}$ re-absorption. Cadmium toxicity lowers the oxygen level in blood and increases free radicals. Detoxification of these free radicals needs antioxidants. Better food and fruit consumption helps in detoxification mechanism. Cigarette smoke contains high level of $\mathrm{Cd}$ because of the use of fertilizers on tobacco plants. Cadmium toxicity level is directly proportional to cigarette smoke (Kim et al., 2010). About $50-70 \%$ of $\mathrm{Cd}$ is absorbed by the lungs when person smokes which contains $\mathrm{Cd}$. It is observed that in both genders $\mathrm{Cd}$ toxicity level is higher in smokers than nonsmokers (Sarkar et al., 2013). One pack of cigarette contains 20 percent 
Table 2: Sources of Cd in air.

\section{Sr. No. Sources}

$1 \quad$ Factories and industries

2 Inhalation of paint

3 Chimneys and steamers

$4 \quad$ Fertilizers, detergents and petroleum products

$5 \quad \mathrm{Ni} / \mathrm{Cd}$ Batteries, Plastics, Ceramics, Glasses, Paints and enamels, Cadmium Stabilized Polyvinylchloride (PVC) Products, Cadmium Coated Ferrous and Non-ferrous Products, Cadmium Alloys and Cadmium Electronic Compounds

6 Smelting, refining and extraction of alloys containing $\mathrm{Cd}$ as an impurity

7 Industrial processes such as nuclear fission and welding etc.

8 Solar panels and optical windows

\section{References}

(Tinkov et al., 2017)

(Genchi et al., 2020)

(Sardar et al, 2013)

(Godt et al., 2006; Bernhoft et al., 2013)

(Nawrot et al., 2006)

(Lamastra et al., 2018)

(Bernhoft et al., 2013)

(Nawaz et al., 2004)

Table 3: Sources of Cd in soil.

\section{S.No Sources}

\section{References}

1 Industrial areas, mine tailings, disposal of high metal wastes, leaded gasoline and paints, land appli-

(Wuana et al., 2011) cation of fertilizers, animal manures, sewage sludge, pesticides, wastewater irrigation, coal combustion residues, spillage of petrochemicals, and atmospheric deposition

2 Acid rain

3 Chemical and biological treatment of industrial and municipal waste

(Campbell et al., 2007)

$4 \quad$ Metal adulteration in soil

(Herath et al., 2015)

(Jarup et al., 1998)

Table 4: Impacts of Cd toxicity on Plants based upon the target action.

\section{S. No Impact}

1 Elevation of secretion of abscisic acid (ABA)

Chlorosis, necrosis, tip burn, degeneration of mitochondria, change in vein color from green to red

3 Reduce the photosynthetic activity, affect the stomata opening and closing pattern, lessen the crop production

4 Chloroplast destruction

5 Changes in nutrient uptake, disturbance in structure and function

6 Disturbance in nitrogen metabolic activity and cause variations in biogeochemical functioning
Target

Seeds

Leaves

\section{Reference}

(Amirjani, 2012)

(Khan et al., 2017;

Ahmad et al., 2012)

Leaves (Sarwar et al., 2014)

Roots

(Rizwan et al., 2016)

Metabolism (Rizwan et al., 2016)

Metabolism (Khan et al., 2017) more $\mathrm{Cd}$ than contaminated food as it contains $2 \mu \mathrm{g}$ of Cd (Akesson et al., 2009). Tobacco smoke is the main reason of chronic obstructive pulmonary disease (COPD) (Figure 2, Table 6).

\section{Strategies to control Cd toxicity in plants}

Nowadays environmental pollution is the crucial dilemma at global level. The pollution is not only limited to atmosphere but also it has major concern with other environmental constituents like water sources (surface and ground), soil, vegetation, humans, animals. Cadmium toxicity in plants occurs through soil contamination. Cadmium in the soil is accumulated in root and then spreads in edible parts of plant which is consumed by the humans and animals (Singh et al., 2007; Ghoochani et al., 2018). At present, many techniques are being employed to remediate the $\mathrm{Cd}$ pollution from soil. To decontaminate the water many plants species are also being used e.g. Moringa, peanuts, cowpeas, urad, and corn. These plants accumulate the $\mathrm{Cd}$ and neutralize its effects (Nand et al., 2012; Wuana et al., 2010). Different chemical methods are being used for cadmium removal such as washing and leaching flushing electro-migration.

As shown in the (Figure 4) phytoremediation is also one of the techniques that are being widely used for the remediation process. Specific plant species with particular characteristics are used for soil remediation i.e., plants act as the accumulator hub for pollutant. 
Such photoremediator plans should have expeditious growth and high yield. Almost 450 plant species have been identified for metal accumulation like green liver is used for xenobiotics and heavy metals (Mahajan and Kaushal, 2018; Macek et al., 2000). Phytoremediation is a combination of different techniques e.g, phytoimmobilization, phytostabilization, Phytoextraction, Phytostabilization, Rhizofltration, Phytofiltration (Padmavathiamma and Li, 2007).

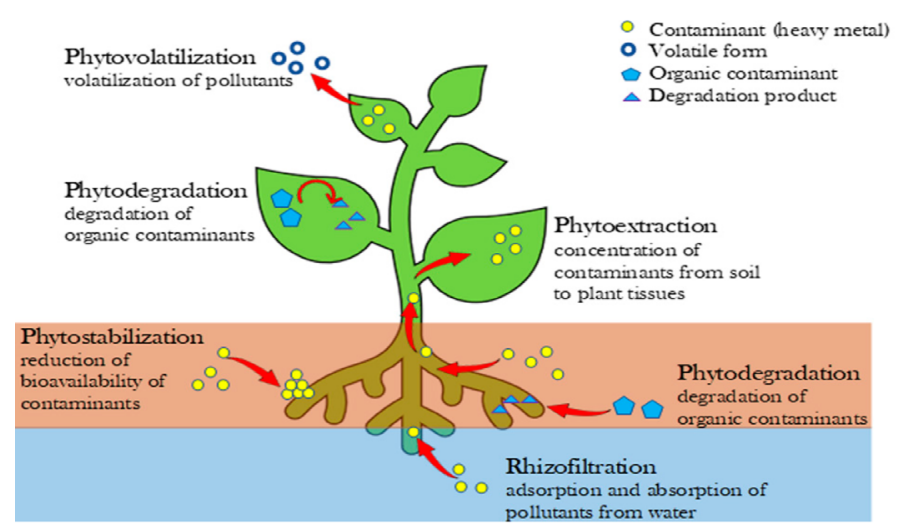

Figure 4: Role of phytoremediation in reducing $C d$ toxicity in soil and water (Mahajin and Kaushal, 2018).

For $\mathrm{Cd}$ accumulation those plants are used which have ability to accumulate the higher concentration of Cd (Rosenfeld et al., 2018). Every plant has its own storage capacity. It is not much difficult task to eliminate the $\mathrm{Cd}$ from soil, because it has high mobility as it cannot make stronger bond with other elements and easily pass to other parts of the plant. In 1990's, Tlaspi caerulescens was the first plant explored as good accumulator of soil $\mathrm{Cd}$ because of its hairy root system (Sheoran et al., 2010). (Mahajan and Kaushal, 2018) have shown that garlic has ability to uptake cadmium from soil and transport it to its different parts and minimize the level of $\mathrm{Cd}$ in the soil. The phytofiltration is other one technique being used for pollutant removal from an aqueous solution by using plants. In this method the roots and seeds act as the accumulation hub. Plants grown in water, involves chemisorption, complexation, ion exchange, micro precipitation, hydroxide condensation onto the bio-surface, and surface adsorption (Verbruggen et al., 200). According to pollutant type and dose, phytoremediating plants alter their chemical processes for taking up the pollutants from soil or solution (Islam et al., 2015).

Rhizofiltration is also good technique which is based on hydrophonic farming. Hydrophonics is a type of horticulture in which plants and crops usually grow without soil, by using mineral and nutrient solutions in an aqueous solvent. After rising in aqueous solution, hydrophinic plants are shifted at contaminated site area. It works on the same principal as phytoextraction, roots and shoot absorb pollutants including $\mathrm{Cd}$, applicable for heavy metals as well as radioactive metals. Plant preference for rhizofiltration depends on plant structure and root surface area as more hairy roots means more surface area and more contaminants can be removed. Mustard and sunflower act as rhizofilter plants (Mahajan and Kaushal, 2018; Dushenkov et al., 1995; Kumar et al., 2021).

In the process of phytoextraction toxic metals are ingested by the plants and, transported to different parts of plants where these toxic metals can be extracted by cutting those parts. Sometime it is not useful as much as considered because it can eliminate essential metal along with toxic metals. It can eliminate copper, potassium, phosphorus, nickel, lead, iron as well as boron, cadmium, chromium, mercury and argon. There is one limitation in this remedy; it only gives best result on those sites where toxicity/metal contamination level is low (Padmavathiamma and Li, 2007). These plants should remove metal with great speed in less time, accumulate metals in high concentration, should have fast growth and (4) have capacity to accumulate metals in high amount (Swain et al., 2014).

Phytostabilization is also a popular technique for the removal of pollutants from the soil by the use of certain plants which are low budget and easy to apply. Roots act as a sucker and accumulator for $\mathrm{Cd}$ in this technique and other toxic metals stuck at root areas. Cadmium suction at root restricts $\mathrm{Cd}$ movement into the underground water as well as in aerial parts of the plants. Soil can be reclaimed and vegetation can grow well by using this technique (Cunningham and Berti, 2000). It only works to immobilize the $\mathrm{Cd}$ movement in soil rather than to eradicate it (Huang et al., 1997). Phytostabilization shows poor results when affected area is highly contaminated (Tordoof et al., 2000). Similarly, when $\mathrm{Cd}$ intake is in its pure form, plants usually die out.

It has been observed that if a person's weight is $70 \mathrm{~kg}$, $5 \mathrm{~g}$ of $\mathrm{Cd}$ is enough for death. In this case, there is urgent need to save the life by vomiting and stomach cleaning. Stomach cleaning can be done orally (mouth) and nasogastric (nose) by using a tube (Nelson and Hawland, 2019). Another medical treatment 
Table 5: Impacts of Cd toxicity on plants based upon plant specificity action.

\begin{tabular}{|c|c|c|c|c|c|c|c|}
\hline $\begin{array}{l}\text { S. } \\
\text { No. }\end{array}$ & $\begin{array}{l}\text { Plant } \\
\text { species }\end{array}$ & Medium & $\begin{array}{l}\text { Experimental } \\
\text { conditions }\end{array}$ & Duration & Cadmium level & Effect & Reference \\
\hline 1 & Rice & $\begin{array}{l}\text { Petri dishes } \\
\text { hydroponically }\end{array}$ & Incubator & 12 days & $5 \mathrm{mM}$ ofC $\mathrm{dCl} 2$ & $\begin{array}{l}\text { Chlorosis of leaves and reduction } \\
\text { in the rate photosynthesis. }\end{array}$ & $\begin{array}{l}\text { (Hsu and Kao } \\
\text { 2007) }\end{array}$ \\
\hline 2 & Wheat & $\begin{array}{l}\text { Nutrient } \\
\text { medium }\end{array}$ & Greenhouse & 2 months & $1 \mathrm{mg} / \mathrm{L}$ ofCdCl${ }_{2}$ & $\begin{array}{l}\text { Reduced the root elongation, plant } \\
\text { height, production of dry mass and } \\
\text { number of tillers/plant. }\end{array}$ & $\begin{array}{l}\text { (Zhang et al., } \\
\text { 2000) }\end{array}$ \\
\hline 3 & Maize & Soil medium & Pot experiment & 2.5 months & $\begin{array}{l}100 \mathrm{mg} \mathrm{kg}^{-1} \text { of } \\
\mathrm{CdSO}_{4}\end{array}$ & $\begin{array}{l}\text { Inhibited root elongation and } \\
\text { reduced dry yield and uptake of } \\
\text { nutrient. }\end{array}$ & $\begin{array}{l}\text { (Shen et al., } \\
\text { 2006) }\end{array}$ \\
\hline 4 & Tomato & $\begin{array}{l}\text { Sand culture } \\
\text { medium }\end{array}$ & Pot experiment & 1 month & $\begin{array}{l}220 \mathrm{ppm} \text { of } \\
\mathrm{CdSO}_{4}\end{array}$ & $\begin{array}{l}\text { Reduced germination of seeds, } \\
\text { root elongation and growth of } \\
\text { plant. }\end{array}$ & $\begin{array}{l}\text { (Baruah et al., } \\
\text { 2019) }\end{array}$ \\
\hline 5 & Spinach & Polluted soil & Pot experiment & 2 months & $\begin{array}{l}100 \mathrm{mg} \mathrm{kg}^{-1} \text { of } \\
\mathrm{CdCl}_{2}\end{array}$ & $\begin{array}{l}\text { High content of cadmium in } \\
\text { leaves and inhibited growth of } \\
\text { plant and development. }\end{array}$ & $\begin{array}{l}\text { (Younis et al., } \\
\text { 2016) }\end{array}$ \\
\hline 6 & Pea & $\begin{array}{l}\text { Nutrient } \\
\text { medium }\end{array}$ & $\begin{array}{l}\text { Climate cham- } \\
\text { ber }\end{array}$ & 1 month & $250 \mu \mathrm{M}$ of $\mathrm{CdCl}_{2}$ & $\begin{array}{l}\text { Reduction in rate of photosynthe- } \\
\text { sis and stomatal density. }\end{array}$ & $\begin{array}{l}\text { (Hediji et al., } \\
\text { 2015) }\end{array}$ \\
\hline
\end{tabular}

of $\mathrm{Cd}$ removal is use of ethylene diamine tetra acetic acid (EDTA). Cadmium poisoning treatment is done within 24 hours. Inject $500 \mathrm{mg}$ of EDTA in body with $50 \mathrm{mg} / \mathrm{kg}$ of glutathione for 2 weeks give good results (Gil et al., 2011). Another medical treatment is the use of Dimercaprol (BAL) in injection form into muscle (Rahimzadeh et al., 2017). It is effective only at first 3 hours of poisoning. Its effectiveness can be enhanced with the medication. Side effects of BAL usage include reduced $\mathrm{Cd}$ level in kidney and kidney functioning (Lapus, 2004).

\section{Conclusion and Recommendation}

It can be concluded that $\mathrm{Cd}$ causes adverse health effects on environment, humans, animals, and vegetation (plants, crops). So it is very necessary to avoid the use of contaminated water for drinking and irrigation as heavy metals accumulate in the different parts of vegetables. Some vegetables when used uncooked e.g. lettuce, cabbage, beets, coriander, radishes, carrots, spinach and parsley etc. can transfer $\mathrm{Cd}$ into the body. Sludge application on vegetation is the main source of $\mathrm{Cd}$ and direct exposure to human body. Similarly, $\mathrm{Cd}$ exposure to plants results in chemical interaction between heavy metals and other micro and macro nutrients. Cadmium toleration in plants and humans involve different strategies which are sometime very cheap and effective. To minimize the $\mathrm{Cd}$ toxicity in soil, there is need to continuously monitor the land and minimize the long term use of sludge for fertili- ty. On the basis of excellent results, phytoremediation is considered as the most convenient technology for $\mathrm{Cd}$ removal. Up till now about 500 plant species have been identified which can serve as a $\mathrm{Cd}$ detoxifier at physiological and molecular level. There is an urgent need of environmental management system to reduce the human exposure and lower the $\mathrm{Cd}$ level. On the basis of research analysis, it is confirmed that $\mathrm{Cd}$ effects on both genders without any discrimination including pregnant women and babies. Smokers are considered more vulnerable to $\mathrm{Cd}$ toxicity. At occupational level, $\mathrm{Cd}$ exposure can be minimized by the use of personal protection equipment (PPE's). Moreover, there should be a proper management system for recycling of $\mathrm{Cd}$ containing products.

\section{Novelty Statement}

This review will help to understand the environmental problems due to $\mathrm{Cd}$ toxicity and their management through the employment of different strategies.

\section{Authors Conribution}

Khaliq Dad: Collected literature.

Muhammad Nawaz: Supervised and correspond the article.

Muhamamd Ibrahim: Helped in data collection on Cd refinement.

Fengliang Zhao: Proof read and wrote the manuscript. 
Table 6: Impacts of Cd on humans.

\section{S. No. Impact}

Cancer

2 Organ damage

Cancer, osteomalacia, change in genetic material

4 Disorders in biological functioning

5

Epigenetic changes, chromosomal abnormalities, mutation in sister chromatid, breakdown of DNA strands, stops cell respiration mechanism, inhibit enzymatic activity tubular necrosis

7 Cancer and stomach irritation, abdominal pain, sickness, vomiting and diarrhea, throat infection, headaches

Abnormalities in organs

Failure in organ functioning

Bones

Shortness of breath loss of smell ability Lungs and immune system

(anosmia) and coryza and hyaline, dyspnoea and wheezing, chest pain and precordial constriction, lower the hemoglobin level, damage to immune cells, DNA

12 High blood pressure, atherosclerosis, Blood and heart disease cholesterol blockage in arteries, cardiac arrest, heart attack, coronary artery disease, and stroke

13 Disturbance in biological process of re- Reproductive system and placenta productive organs, stops production of progesterone and testosterone, reduction in sperm production, density and volume, immature gamete formation

Target pancreas, stomach, cervix

Kidney and liver

Kidney system

Kidney
Lungs, larynx, mouth, throat, bladder, liver,

Prostate, renal, breast and other cancer, stomach irritation, abdominal pain, sickness, vomiting and diarrhea, throat infection, headaches Liver, kidney, lungs, testes, prostate, heart, skeletal system, nervous system and immune

(Peters et al., 2010; Tellez et al., 2013; Nawrot et al., 2010; Tinkov et al., 2018; Wang and Wie, 2014)

(Folar, 2009; Godt et al., 2006; Fery et al., 1993; Henson and Chedrese, 2004; Rahimzadeh et al., 2017; Thompson and Bannigan, 2008; Pizent et al., 2012; Goyer et al., 1992; Wing et al., 1992; Jarup et al., 1998)
Rumsha Hassan: wrote up of refinement strategies. Humaira Nawaz: Wrote abstract and introduction. Muhammad Usman Saleem: Wrote the portion of Cd impacts on plants.

Kinat Javed: Figure slection and their interpretation. Ayesha Komal and Hajra Naz: Helped in tabulated work.
Conflict of interest

There is no conflict of interest

\section{References}

Abbas,T.,M.Rizwan,S.Ali,M.Zia-ur-Rehman,M. F. Qayyum, F. Abbas andY.S. Ok. 2017. Effect of biochar on cadmium bioavailability and uptake in wheat (Triticum aestivum L.) grown in a soil 
with aged contamination. Ecotoxicol. Environ. Safety. 140:37-47. https://doi.org/10.1016/j. ecoenv.2017.02.028

Amirjani, M. 2012. Effects of cadmium on wheat growth and some physiological factors. Int. J. For. Soil Erosion. 2(1):50-58.

Ahmad, M., H. An, Y.S. Kim, J.H. Lee, J. Jung, S.H. Chun and Y. Seo. 2012. Nanoscale investigation of charge transport at the grain boundaries and wrinkles in graphene film. Nanotechnol. 23(28):285705. https://doi. org/10.1088/0957-4484/23/28/285705

Alloway, B.J. and E. Steinnes. 1999. Anthropogenic additions of cadmium to soils. In Cadmium in soils and plants (pp. 97-123). Springer, Dordrecht. https://doi.org/10.1007/978-94011-4473-5 5

Åkesson, A., B. Julin and A. Wolk. 2008. Long-term dietary cadmium intake and postmenopausal endometrial cancer incidence: a population-based prospective cohort study. Cancer Res. 68(15): 6435-6441. https:// doi.org/10.1158/0008-5472.CAN-08-0329

Åkesson, A., L. Barregard, I.A. Bergdahl, G.F. Nordberg, M. Nordberg and S. Skerfving. 2014. Non-renal effects and the risk assessment of environmental cadmium exposure. Environ. Health Perspect. 122(5): 431-438. https://doi. org/10.1289/ehp.1307110

Bernard, A. and R. Lauwerys. 1986. Effects of cadmium exposure in humans. In Cadmium (pp. 135-177). Springer, Berlin, Heidelberg. https:// doi.org/10.1007/978-3-642-70856-5_5

Bernhoft, R.A. 2013. Cadmium toxicity and treatment. Scient. World J. 2013: pp. 7. https:// doi.org/10.1155/2013/394652

Blanusa, M., V.M. Varnai, M. Piasek and K. Kostial. 2005. Chelators as antidotes of metal toxicity: therapeutic and experimental aspects. Current medicinal chemistry, 12(23):2771-2794. https://doi.org/10.2174/092986705774462987

Baruah, N., C.M. Subham,M. Farooq,N. Gogoi. 2019. Influence of heavy metals on seed germination and seedling growth of wheat, pea, and tomato. Water Air Soil Pollut. 230, 273288. https://doi.org/10.1007/s11270-0194329-0

Bernhoft, R.A. 2013. Cadmium toxicity and treatment. Scient. World J. https://doi. org/10.1155/2013/394652

Boonprasert, K., P. Kongjam, P. Limpatanachote, R.
Ruengweerayut and K. Na-Bangchang. 2011. Urinary and blood cadmium levels in relation to types of food and water intake and smoking. status in a Thai population residing in cadmiumcontaminated areas in Mae Sot. Southeast Asian J. Trop. Med. Public Health. 42(6):1521.

Benavides, M.P., S.M. Gallego andM.L. Tomaro. 2005. Toxicidade de cádmio em plantas. Brazilian J. Plant Physiol. 17(1):21-34 https://doi. org/10.1590/S1677-04202005000100003

Campbell, P.G. 2007. Cadmium-a priority pollutant. Environ. Chem. 3(6): 387-388. https://doi.org/10.1071/EN06075

Cunningham, S.D. and W.R. Berti. 2000. Phytoextraction and phytostabilization: technical, economic and regulatory considerations of the soil-lead issue. Phytorem. Contaminated Soil and Water. https://doi. org/10.1201/9781439822654.ch19

Chaney, R.L. and D.P. Oliver.1996. Sources, potential adverse effects and remediation of agricultural soil contaminants. In Contaminants and the soil environment in the AustralasiaPacific region (pp. 323-359). Springer, Dordrecht. https://doi.org/10.1007/978-94009-1626-5_11

Cieslinski, G., K.C.J. Van Rees, A.M. Szmigielska, G.S.R. Krishnamurti and P. M. Huang. 1998. Low-molecular-weight organic acids in rhizosphere soils of durum wheat and their effect on cadmium bioaccumulation. Plant and soil. 203(1): 109-117. https://doi. org/10.1023/A:1004325817420

Council, N. 2003. Nordic Council of Ministers Cadmium review Nordic Council of Ministers cadmium review. WHO, Geneva.

Dahlin, A.S., J. Eriksson,C.D. Campbell and I. Öborn. 2016. Soil amendment affects Cd uptake by wheat-are we underestimating the risks from chloride inputs?. Science of the Total Environment, 554:349-357. https://doi. org/10.1016/j.scitotenv.2016.02.049

Dushenkov, V., P.N. Kumar, H. Motto and I. Raskin. 1995. Rhizofiltration: the use of plants to remove heavy metals from aqueous streams. Environ. Sci. Technol. 29(5):12391245. https://doi.org/10.1021/es00005a015

Ebrahimi, M., N. Khalili, S. Razi, M. KeshavarzFathi, N. Khalili and N. Rezaei. 2020. Effects of lead and cadmium on the immune system and cancer progression. J. Environ. Health Sci. 
Eng. 18(1):335-343. https://doi.org/10.1007/ s40201-020-00455-2

Frery, N., C. Nessmann, F. Girard, J. Lafond, T. Moreau, P. Blot and G. Huel. 1993. Environmental exposure to cadmium and human birthweight. Toxicology. 79(2):109$118 . \quad$ https://doi.org/10.1016/0300483X(93)90124-B

Filipič, M. 2012. Mechanisms of cadmium induced genomic instability. Mut. Res. /Fundam. Mol. Mech. Mutagen. 733(1-2):69-77. https://doi. org/10.1016/j.mrfmmm.2011.09.002

Fatima, G., A.M. Raza, N. Hadi, N. Nigam and A.A. Mahdi. 2019. Cadmium in human diseases: It's more than just a mere metal. Indian J. Clin. Biochem. 34(4):371-378. https://doi. org/10.1007/s12291-019-00839-8

Fowler, B.A. 2009. Monitoring of human populations for early markers of cadmium toxicity: a review. Toxicol. Appl. Pharmacol. 238(3):294-300. https://doi. org/10.1016/j.taap.2009.05.004

Fytili, D. and A. Zabaniotou. 2008. Utilization of sewage sludge in EU application of old and new methods-a review. Renew. Sustain. energy Rev. 12(1):116-140. https://doi.org/10.1016/j. rser.2006.05.014

Genchi, G., M.S. Sinicropi, G. Lauria, A. Carocci and A. Catalano. 2020. The effects of cadmium toxicity. Int. J. Environ. Res. Public Health. 17(11):3782. https://doi.org/10.3390/ ijerph17113782

Godt, J., F. Scheidig,C. Grosse-Siestrup, V. Esche, P. Brandenburg, A. Reich and D.A. Groneberg. 2006. The toxicity of cadmium and resulting hazards for human health. J. Occup. Med. Toxicol. 1(1): 1-6. https://doi. org/10.1186/1745-6673-1-22

Ghoochani, M., N. Rastkari, M. Yunesian, R.N. Nodehi, A. Mesdaghinia, A. Houshiarrad and M.H. Dehghani. 2018. What do we know about exposure of Iranians to cadmium? Findings from a systematic review. Environ. Sci. Pollut. Res. 25(2):1-11. https://doi.org/10.1007/ s11356-017-0863-8

Gustin,K.,F.Tofail,M.Vahter and M.Kippler.2018. Cadmium exposure and cognitive abilities and behavior at 10 years of age: a prospective cohort study. Environ. Int. 113:259-268. https://doi. org/10.1016/j.envint.2018.02.020

Goyer, R.A. and M.G. Cherian. 1992. Role of metallothionein in human placenta and rats exposed to cadmium. IARC scientific publications. (118):239-247.

Ganguly, K., B. Levänen, L. Palmberg, A. Åkesson and A. Lindén. 2018. Cadmium in tobacco smokers: a neglected link to lung disease? Eur. Respir. Rev. 27(147). https://doi. org/10.1183/16000617.0122-2017

Gil, H.W., E.J. Kang, K.H. Lee, J.O. Yang, E.Y. Lee and S.Y. Hong. 2011. Effect of glutathione on the cadmium chelation of EDTA in a patient with cadmium intoxication. Human Exp. Toxicol. 30(1):79-83. https://doi. org/10.1177/0960327110369818

Herath, I., P. Kumarathilaka, A. Navaratne, N. Rajakaruna and M. Vithanage. 2015. Immobilization and phytotoxicity reduction of heavy metals in serpentine soil using biochar. J. Soils Sediments. 15(1):126-138. https://doi. org/10.1007/s11368-014-0967-4

Hediji,H.,W.Djebali, A. Belkadhi, C.Cabasson, A. Moing, D. Rolin and W. Chaibi. 2015. Impact of long-term cadmium exposure on mineral content of Solanum lycopersicum plants: consequences on fruit production. South Afr. J. Bot. 97:176-181. https://doi.org/10.1016/j. sajb.2015.01.010

Henson, M.C. and P.J. Chedrese. 2004. Endocrine disruption by cadmium, a common environmental toxicant with paradoxical effects on reproduction. Exp. Biol. Med. 229(5):383-392. https://doi. org $/ 10.1177 / 153537020422900506$

Huang, J.W., J. Chen, W.R. Berti and S.D. Cunningham. 1997. Phytoremediation of lead-contaminated soils: role of synthetic chelates in lead phytoextraction. Environ. Sci. Technol. 31(3):800-805. https://doi. org/10.1021/es9604828

Hossein-Khannazer, N., G. Azizi, S. Eslami, H. Alhassan Mohammed, F. Fayyaz, R. Hosseinzadeh and M. Noorisepehr. 2020. The effects of cadmium exposure in the induction of inflammation. Immunopharmacol. Immunotoxicol. 42(1):1-8. https://doi.org/10. 1080/08923973.2019.1697284

Hsu, Y.T. and C.H. Kao, 2007. Toxicity in leaves of rice exposed to cadmium is due to hydrogen peroxide accumulation. Plant Soil 298:231-241. https://doi.org/10.1007/s11104-007-9357-7

Islam, M.S., T. Saito and M. Kurasaki. 2015. 
Phytofiltration of arsenic and cadmium by using an aquatic plant, Micranthemum umbrosum: Phytotoxicity, uptake kinetics, and mechanism. Ecotoxicol. Environ. Safety. 112:193-200. https://doi.org/10.1016/j. ecoenv.2014.11.006

Jarup, L., M. Berglund, C.G. Elinder, G. Nordberg and M. Vanter. 1998. Health effects of cadmium exposure-a review of the literature and a risk estimate. Scand.J. Work Environ. Health.1-51.

Joseph, P. 2009. Mechanisms of cadmium carcinogenesis. Toxicol. Appl. Pharmacol. 238(3): 272-279. https://doi. org/10.1016/j.taap.2009.01.011

Jaishankar, M., T. Tseten, N. Anbalagan, B.B. Mathew and K.N. Beeregowda. 2014. Toxicity, mechanism and health effects of some heavy metals. Interdiscip. Toxicol. 7(2):60. https:// doi.org/10.2478/intox-2014-0009

Kumar, V., A. Kaushal, M.P. Shah and K. Singh. 2021. Phytoaugmentation technology for phytoremediation of environmental pollutants: current scenario and future prospects. In Bioremediation for Environmental Sustainability (pp. 329-381). Elsevier. https:// doi.org/10.1016/B978-0-12-820318-7.000162

Khan, M.A., S. Khan, A. Khan and M. Alam. 2017. Soil contamination with cadmium, consequences and remediation using organic amendments. Sci. Total Environ. 601: 1591-1605. https://doi.org/10.1016/j. scitotenv.2017.06.030

Kaewnate, Y., S. Niyomtam, O. Tangvarasittichai, S. Meemark, P. Pingmuangkaew and S. Tangvarasittichai. 2012. Association of elevated urinary cadmium with urinary stone, hypercalciuria and renal tubular dysfunction in the population of cadmiumcontaminated area. Bull. Environ. Contam. Toxicol. 89(6):1120-1124. https://doi. org/10.1007/s00128-012-0856-8

Kim, H., H.J. Lee, J.Y. Hwang, E.H. Ha, H. Park, M. Ha and N. Chang. 2010. Blood cadmium concentrations of male cigarette smokers are inversely associated with fruit consumption. J. Nut. 140(6): 1133-1138. https://doi. org/10.3945/jn.109.120659

Lamastra, L., N.A. Suciu and M. Trevisan. 2018. Sewage sludge for sustainable agriculture: contaminants' contents and potential use as fertilizer. Chem. Biol. Technol. Agric. 5(1):1-6 https://doi.org/10.1186/s40538-018-0122-3.

Lasat, M.M. 1999. Phytoextraction of metals from contaminated soil: a review of plant/soil/ metal interaction and assessment of pertinent agronomic issues. J. Hazard. Subst. Res. 2(1):5 https://doi.org/10.4148/1090-7025.1015.

Lin, Y.F. and M.G. Aarts. 2012. The molecular mechanism of zinc and cadmium stress response in plants. Cel. Mol. Life sci. 69(19):3187-3206 https://doi.org/10.1007/s00018-012-1089-z.

Lapus, R.M. 2007. Activated charcoal for pediatric poisonings: the universal antidote? Curr. Opin. Pediatr. 19(2):216-222. https://doi. org/10.1097/MOP.0b013e32801da2a9

Morrow, H. 2003. The Release of Cadmium to the Environment Due to Corrosion from Anthropogenic Sources. BULLETINKORROSIONSINSTITUTET. 83-96.

Mahajan, P. and J. Kaushal. 2018. Role of phytoremediation in reducing cadmium toxicity in soil and water. J. Toxicol. 2018. https://doi. org $/ 10.1155 / 2018 / 4864365$

Mattigod, S.V. and A.L. Page. 1983. Assessment of metal pollution in soils. Appl. Environ. Geochem. 1.

Macek, T., M. Macková and J. Káš. 2000. Exploitation of plants for the removal of organics in environmental remediation. Biotechnol. Adv. 18(1):23-34. https://doi.org/10.1016/ S0734-9750(99)00034-8

Nelson, L.S., M.A. Howland and N.A. Lewin. 2019. Goldfrank's toxicologic emergencies. McGraw-Hill Education.

Nawrot, T.S. and J.A. Staessen. 2006. Low-level environmental exposure to lead unmasked as silent killer. https://doi.org/10.1161/ CIRCULATIONAHA.106.650440

Navas-Acien, A., E. Selvin,A.R. Sharrett,E. Calderon-Aranda,E. Silbergeld and E. Guallar. 2004. Lead, cadmium, smoking, and increased risk of peripheral arterial disease. Circulation. 109(25):31963201. https://doi.org/10.1161/01. CIR.0000130848.18636.B2

Nemery, B. 1990. Metal toxicity and the respiratory tract. Eur. Respir. J. 3(2):202-219.

Nawrot, T.S., J.A. Staessen, H.A. Roels, E. Munters, A. Cuypers, T. Richart and J. Vangronsveld. 2010. Cadmium exposure in the population: from health risks to strategies of 
prevention. Biometals. 23(5):769-782. https:// doi.org/10.1007/s10534-010-9343-z

Nordberg, G.F., B.A. Fowler and M. Nordberg. 2014. Handbook on the Toxicology of Metals. Academic press. https://doi.org/10.1016/ B978-0-444-59453-2.00001-9

Nand, V., M. Maata, K. Koshy and S. Sotheeswaran. 2012. Water purification using moringa oleifera and other locally available seeds in Fiji for heavy metal removal. Int. J. Appl. Sci. Technol. 2(5).

Orr, S.E. and C.C. Bridges. 2017. chronic kidney disease and exposure to nephrotoxic metals. Int. J. Mol. Sci. 18(5):1039. https://doi. org/10.3390/ijms18051039

Perveen, S., A.B.D.U.S. Samad, W. Nazif and S. Shah. 2012. Impact of sewage water on vegetables quality with respect to heavy metals in Peshawar, Pakistan. Pak. J. Bot. 44(6): 19231931. https://doi.org/10.1007/978-1-46158498-8 1

Page, A.L. and F.T. Bingham. 1973. Cadmium residues in the environment. Residue Rev. 1-44.

Perc, M., J. Gómez-Gardenes, A. Szolnoki, L.M. Floría and Y. Moreno. 2013. Evolutionary dynamics of group interactions on structured populations: a review. J. Royal Soc. Interface. 10(80):20120997. https://doi. org/10.1098/rsif.2012.0997

Padmavathiamma, P. K. and L.Y. Li. 2007. Phytoremediation technology: hyperaccumulation metals in plants. Water Air Soil Pollut. 184(1):105-126. https://doi. org/10.1007/s11270-007-9401-5

Peters, J.L., T.S. Perlstein, M.J. Perry, E. McNeely and J. Weuve. 2010. Cadmium exposure in association with history of stroke and heart failure. Environ. Res. 110(2):199-206. https:// doi.org/10.1016/j.envres.2009.12.004

Patrick, L. 2003. Toxic metals and antioxidants: part II. The role of antioxidants in arsenic and cadmium toxicity. Altern. Med. Rev. 8(2).

Pizent, A., B. Tariba and T. Živković. 2012. Reproductive toxicity of metals in men. Arch. Ind. Hyg. Toxicol. 63(Supplement-1):35-46. https://doi.org/10.2478/10004-1254-632012-2151

Rizwan, M., S. Ali, T. Abbas, M. Zia-ur-Rehman, F. Hannan,C. Keller and Y.S. Ok. 2016. Cadmium minimization in wheat: a critical review. Ecotoxicol. Environ. Safety. 130:43-53. https://doi.org/10.1016/j.ecoenv.2016.04.001
Rosenfeld, C.E., R.L. Chaney and C.E. Martínez. 2018. Soil geochemical factors regulate $\mathrm{Cd}$ accumulation by metal hyperaccumulating Noccaea caerulescens (J. Presl \& C. Presl) FK Mey in field-contaminated soils. Sci. Total Environ. 616:279-287. https://doi. org/10.1016/j.scitotenv.2017.11.016

Rahimzadeh, M.R., M.R. Rahimzadeh, S. Kazemi and A.A. Moghadamnia. 2017. Cadmium toxicity and treatment: An update. Caspian J. Intern. Med. 8(3):135.

Sarkar, A., G. Ravindran and V. Krishnamurthy. 2013. A brief review on the effect of cadmium toxicity: from cellular to organ level. Int. J. Biotechnol. Res. 3(1):17-36.

Scragg, A.H. 2005. Environmental biotechnology. New York: OXFORD university press.

Sumner, M.E. 2000. Beneficial use of effluents, wastes, and biosolids. Commun. Soil Sci. Plant Anal. 31(11-14):1701-1715. https://doi. org/10.1080/00103620009370532

Sardar, K., S. Ali, S. Hameed, S. Afzal, S. Fatima, M.B. Shakoor and H.M. Tauqeer.2013. Heavy metals contamination and what are the impacts on living organisms. Green.J. Environ. Manage. public safety. 2(4):172-179. https://doi. org/10.15580/GJEMPS.2013.4.060413652

Song, Y., L. Jin and X. Wang. 2017. Cadmium absorption and transportation pathways in plants. Int. J.of Phytorem. 19(2):133-141. https://doi.org/10.1080/15226514.2016.1207 598

Shen, H., P. Christie, X. Li. 2006. Uptake of zinc, cadmium and phosphorus by arbuscular mycorrhizal maize (Zea mays L.) from a low available phosphorus calcareous soil spiked with zinc and cadmium. Environ. Geochem. Health. 28:111-119. https://doi.org/10.1007/ s10653-005-9020-2

Szolnoki, Z.S., A. Farsang and I. Puskás. 2013. Cumulative impacts of human activities on urban garden soils: origin and accumulation of metals. Environ. Pollut. 177: 106-115. https:// doi.org/10.1016/j.envpol.2013.02.007

Swaddiwudhipong, W., P. Limpatanachote, P. Mahasakpan, S. Krintratun, B. Punta and T. Funkhiew. 2012. Progress in cadmium-related health effectsin persons with high environmental exposure in northwestern Thailand: a five-year follow-up. Environ. Res. 112:194-198. https:// doi.org/10.1016/j.envres.2011.10.004 
Sarwar, N., S. Bibi, M. Ahmad and Y.S. Ok. 2014. Effectiveness of zinc application to minimize cadmium toxicity and accumulation in wheat (Triticum aestivum L.). Environ. Earth sci. 71(4):1663-1672. https://doi.org/10.1007/ s12665-013-2570-1

Singh, R.P. and M. Agrawal. 2007. Effects of sewage sludge amendment on heavy metal accumulation and consequent responses of Beta vulgaris plants. Chemosphere. 67(11):22292240 . https://doi.org/10.1016/j. chemosphere.2006.12.019

Sheoran,V.,A.S.SheoranandP.Poonia.2010.Role of hyperaccumulators in phytoextraction of metals from contaminated mining sites: a review. Crit. Rev. Environ. Sci. Technol. 41(2):168-214. https://doi.org/10.1080/10643380902718418

Swain, G., S. Adhikari and P. Mohanty. 2014. Phytoremediation of copper and cadmium from water using water hyacinth, Eichhornia crassipes. Int. J. Agric. Sci. Technol. 2(1):1-7. https://doi.org/10.14355/ijast.2014.0301.01

Seixas, N.S., T.G. Robins, M.D. Attfield and L.H. Moulton. 1992. Exposure-response relationships for coal mine dust and obstructive lung disease following enactment of the federal coal mine health and safety act of 1969 . Am. J. Ind. Med. 21(5):715-734. https://doi. org/10.1002/ajim.4700210511

Sabolic, I., D. Breljak, M. Škarica and C.M. HerakKramberger. 2010. Role of metallothionein in cadmium traffic and toxicity in kidneys and other mammalian organs. Biometals. 23(5):897-926. https://doi.org/10.1007/s10534-010-9351-z

Scott, G.M. and A. Smith. 1995, May. Sludge characteristics and disposal alternatives for the pulp and paper industry. In Tappi International Environmental Conference (pp. 269-269). Tappi Press.

Tinkov, A.A.V.A. Gritsenko, M.G. Skalnaya, S.V. Cherkasov, J. Aaseth and A.V. Skalny. 2018. Gut as a target for cadmium toxicity. Environ. Pollut. 235:429-434. https://doi.org/10.1016/j. envpol.2017.12.114

Tandi, N.K., J. Nyamangara and C. Bangira. 2004. Environmental and potential health effects of growing leafy vegetables on soil irrigated using sewage sludge and effluent: a case of $\mathrm{Zn}$ and Cu. J. Environ. Sci. Health. Part B. 39(3):461471. https://doi.org/10.1081/PFC-120035930 Teng, X., S. Dey, T. Børvik and T. Wierzbicki. 2007.
Protection performance of double-layered metal shields against projectile impact. J. mech. Mater. Struct. 2(7):1309-1329. https://doi. org/10.2140/jomms.2007.2.1309

Tordoff, G.M., A.J.M. Baker and A.J. Willis. 2000. Current approaches to the revegetation and reclamation of metalliferous mine wastes.Chemosphere.41(1-2):219-228.https:// doi.org/10.1016/S0045-6535(99)00414-2

Tellez-Plaza, M., E. Guallar, B.V. Howard, J.G. Umans, K.A. Francesconi, W. Goessler and A. Navas-Acien. 2013. Cadmium exposure and incident cardiovascular disease. Epidemiology (Cambridge, Mass.), 24(3):421. https://doi. org/10.1097/EDE.0b013e31828b0631

Thompson, J. and J. Bannigan. 2008. Cadmium: toxic effects on the reproductive system and the embryo. Reprod. Toxicol. 25(3):304-315. https://doi.org/10.1016/j.reprotox.2008.02.001

Verbruggen, N., C. Hermans and H. Schat. 2009. Molecular mechanisms of metal hyperaccumulation in plants. New phytologist. 181(4):759-776. https://doi. org/10.1111/j.1469-8137.2008.02748.x

Wuana, R.A. and F.E. Okieimen. 2011. Heavy metals in contaminated soils: a review of sources, chemistry, risks and best available strategies for remediation. Int. Sch. Res. Not. https://doi. org/10.5402/2011/402647

Wing, K., K. Tholin, R. Sjöström,B. Sandström and G. Hallmans. 1992. The relation of the accumulation of cadmium in human placenta to the intake of high-fibre grains and maternal iron status. Eur. J. Clin. Nut. 46(8):585-595.

Wuana, R.A., F.E. Okieimen and J.A. Imborvungu. 2010. Removal of heavy metals from a contaminated soil using organic chelating acids. Int. J. Environ. Sci. Technol. 7(3):485496. https://doi.org/10.1007/BF03326158

Wang, Q. and S. Wei. 2018. Cadmium affects blood pressure and negatively interacts with obesity: findings from NHANES 1999-2014. Sci. Total Environ. 643:270-276. https://doi. org/10.1016/j.scitotenv.2018.06.105

Younis, U., S.A. Malik, M. Rizwan, M.F. Qayyum, Y.S. Ok, M.H.R. Shah, R.A. Rehman, N. Ahmad. 2016. Biochar enhances the cadmium tolerance in spinach (Spinacia oleracea) through modification of $\mathrm{Cd}$ uptake and physiological and biochemical attributes. Environ. Sci. Pollut. Res.23:21385-21394.https://doi.org/10.1007/ 
Zwolak, I. 2020. The role of selenium in arsenic and cadmium toxicity: an updated review of scientific literature. Biol. Trace Elem. Res. 193(1):44-63 https://doi.org/10.1007/s12011-019-01691-w.

Zalups,R.K.andS.Ahmad.2003.Molecularhandling of cadmium in transporting epithelia. Toxicol. Appl. Pharmacol. 186(3):163-188. https://doi. org/10.1016/S0041-008X(02)00021-2

Zhang, G.P., M. Fukami, H. Sekimoto. 2000. Genotypic differences in effects of cadmium on growth and nutrient compositions in wheat. J. Plant Nutr. 23: 1337-1350. https://doi. org/10.1080/01904160009382104 